\title{
Relationships between metallothioneins and metal accumulation in the whelk Thais clavigera
}

\author{
Graham Blackmore, Wen-Xiong Wang*
}

Department of Biology, The Hong Kong University of Science and Technology (HKUST), Clear Water Bay, Kowloon, Hong Kong SAR

\begin{abstract}
Whelks Thais clavigera were collected from field populations containing different concentrations of metallothioneins (MTs) or were pre-exposed to aqueous or dietary Cd in the laboratory to result in differential body $\mathrm{MT}$ concentrations. $\mathrm{Cd}, \mathrm{Hg}$ and $\mathrm{Zn}$ uptake from the dissolved phase, assimilation efficiency from the dietary phase, and body burden were subsequently quantified. MT concentrations in whelks collected from 11 sites in the coastal waters of Hong Kong were significantly correlated with $\mathrm{Cd}$ body concentrations, but were not correlated with $\mathrm{Cu}$ and $\mathrm{Zn}$ body concentrations. There was a clear relationship between the dissolved $\mathrm{Cd}$ exposure and the resultant MT levels in the animals, but no such relationship was found following dietary exposure to $\mathrm{Cd}$. The assimilation of $\mathrm{Cd}$ and $\mathrm{Hg}$ increased in whelks originating from impacted field populations with higher MT levels and following inducement of MTs by pre-exposure to dissolved or dietary Cd. Zn assimilation was comparable in the field populations with different MT levels, but decreased in groups with higher MTs following pre-exposure to Cd, presumably due to the saturation of MTs by Cd binding, and thus less MT binding sites were available for Zn. MTs may thus play an important role in metal assimilation. In contrast to dietary assimilation, metal uptake from the dissolved phase in whelks was unaffected by MT body concentrations. Dissolved uptake appears to be largely a physico-chemical process and is little affected by the intracellular physiological changes made by the animals. Given the ubiquity of MTs in marine animals and the importance of dietary sources in metal accumulation, the influence of MT should be considered in interpreting body metal concentrations, and the use of MTs as biomarkers of metal contamination should be treated with caution.
\end{abstract}

KEY WORDS: Whelk · Metallothioneins $\cdot$ Metals $\cdot$ Pre-exposure $\cdot$ Assimilation $\cdot$ Biomonitoring

\section{INTRODUCTION}

Detection of biomarkers as measurable biochemical and/or physiological alterations may serve as an early warning when compared to other parameters such as growth or reproductive abnormalities, which may not be detected until it is too late to take countermeasures (Langston et al. 2002). Metallothioneins (MTs) are a group of low molecular weight, heat stable and cysteine-rich metal binding proteins which normally bind with metal ions, e.g. $\mathrm{Cd}^{2+}, \mathrm{Hg}^{2+}$ and $\mathrm{Zn}^{2+}$, and are present in many aquatic species (Roesijadi 1992). They play an important role in the storage and supply of essential metals such as $\mathrm{Zn}$ and $\mathrm{Cu}$, which are used during protein synthesis, as well as the detoxification of non-essential metals such as $\mathrm{Cd}$ and $\mathrm{Hg}$ (Hamer 1986, Roesijadi 1992, 1996, Palmiter 1994, Langston et al. 1998). MT synthesis occurs under conditions of elevated metal concentrations, thereby binding excess cellular concentrations of metals. In mammals, $\mathrm{Zn}$ is the most potent inducer of MT synthesis (Palmiter 1994), whereas in marine bivalves $\mathrm{Cd}$ is a much stronger inducer of MTs than Zn (Langston et al. 1998). MTs have a short biological half-life (e.g. $25 \mathrm{~d}$ in the mussel Mytilus edulis) (Bebianno \& Langston 1993) and concentrations will decrease accordingly once metal stress is reduced. MT concentrations are also generally correlated with metal concentrations (George \& Olsson 1994), and as such MTs have been suggested as potential biomarkers for metal pollution 
(Roesijadi 1994). The influence of MT induction on metal bioaccumulation is not well known. To apply MT assays in environmental assessments, however, there must first be validation of the responses of the proposed monitoring species, given the diversity and function of MTs. Furthermore, metals are not the only factors affecting MT levels and expression. For example, temperature, salinity, reproduction state, nutritional state, age/size, and growth rate have all been shown to affect tissue MT concentrations (Olsson et al. 1987, Overnell et al. 1988, Mouneyrac et al. 1998, 2000, Leung \& Furness 1999a,b, Legras et al. 2000, Leung et al. 2000). The high in sensitivity and a measurable response to metal exposure outweigh these shortcomings (Langston et al. 2002). Few studies have however focused on the induction of MTs in marine molluscs following exposure to metals via a dietary route (Blackmore \& Wang 2002, Shi et al. 2003).

Little attention has focused on the effects of MTs on metal bioaccumulation. Blackmore \& Wang (2002) documented that dietary assimilation of $\mathrm{Cd}$, and under certain conditions, $\mathrm{Zn}$, increased in mussels preexposed to $\mathrm{Cd}$. This increase corresponded to an increase in the levels of metallothioneins-like proteins (MTLPs) in the mussels following exposure, suggesting a potential role of MTs in Cd assimilation. Shi et al. (2003) noted a similar increase in Ag assimilation in mussels following pre-exposure to Ag, although there was no concomitant increase in the proportion of MTLPs. Gully \& Mason (1993) reported that both Cd and $\mathrm{Cu}$ were redistributed in the gills of the marine snail Littorina littorea following exposure to $\mathrm{Cd}$. This was related to the affinity of each metal for MTs and the induction of MTs by Cd exposure. These limited studies imply that MTs can have a large effect on metal accumulation.

Interest in metal accumulation in marine molluscs originates from their use as biomonitors of metal pollution (Phillips \& Rainbow 1993). It is important to understand any factors affecting body metal concentrations in biomonitors. Metal exposure can cause alterations in an organism's physiology and such changes can potentially affect metal accumulation (Wang 2002), thus there is a need to examine the evolutionary significance of trace metal contamination. MTs have been measured in many marine invertebrates (Roesijadi

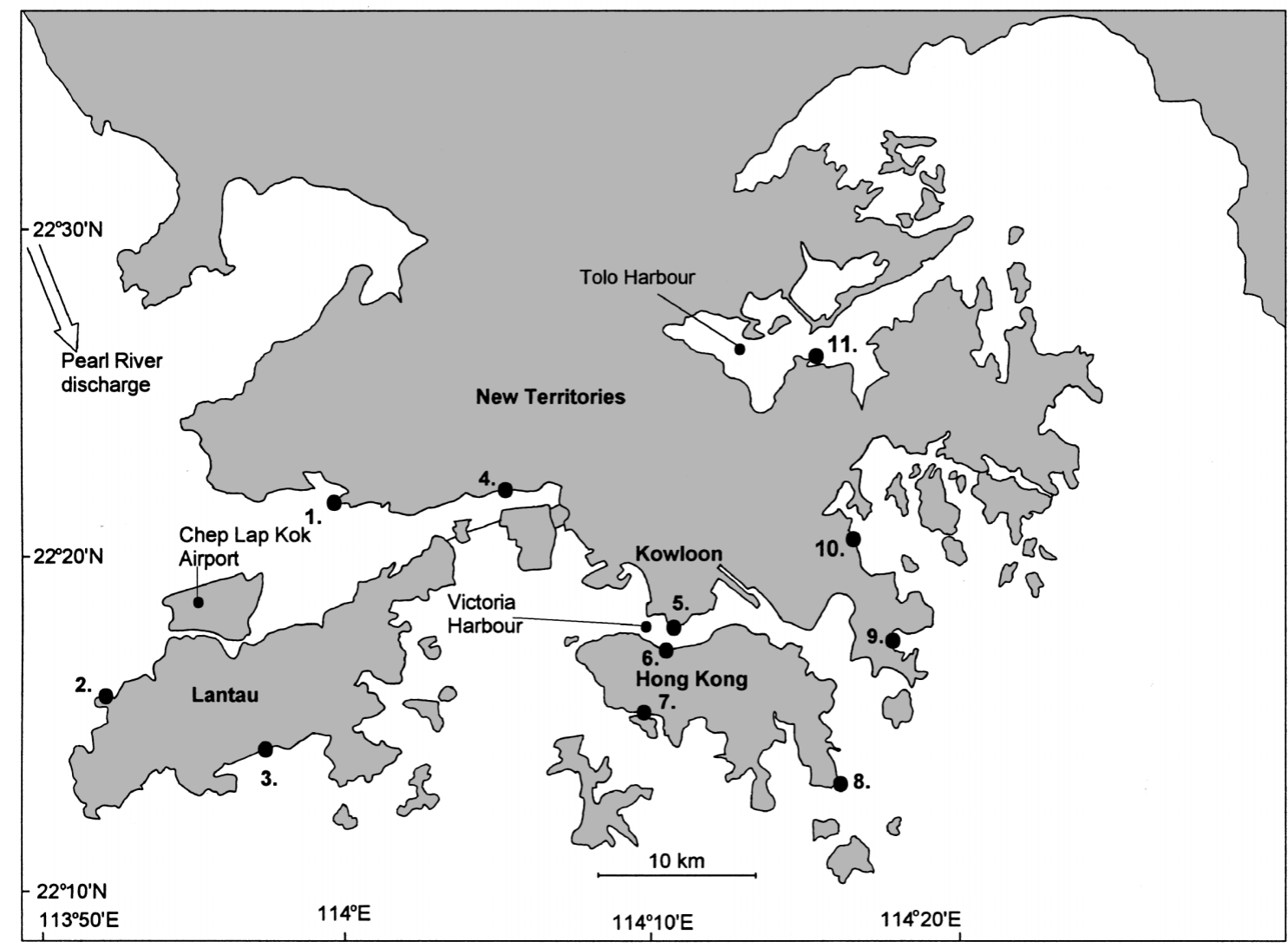

Fig. 1. Hong Kong sampling locations. 1: Tuen Mun, 2: Tai O, 3: South Lantau, 4: Tsing Yi, 5: Queen's Pier, 6: Tsim Sha Tsui, 7: Aberdeen, 8: Cape d'Aguilar, 9: Clear Water Bay, 10: University of Science and Technology (UST), and 11: Starfish Bay 
1992) and may even be ubiquitous. MT body concentrations are affected by a range of natural and anthropogenic factors and importantly, as a metal binding protein, they may have a large effect on metal biology and consequently metal accumulation.

To our knowledge, no previous study has examined the influence of metallothionein concentration on metal biokinetics in field-collected marine invertebrates. In this study, we quantified the effect of different MT concentrations on $\mathrm{Cd}, \mathrm{Hg}$ and $\mathrm{Zn}$ accumulation in the whelk Thais clavigera. This species has a high concentration of MTs especially when compared to bivalves (G. B. \& W.X. W. unpubl. data), thus providing an excellent model to examine the interaction of MTs and metal bioavailability. Previous studies indicated that MTs have an affect on dietary intake of metals (Blackmore \& Wang 2002, Shi et al. 2003) and that predatory snails have a dominance of dietary metal uptake (Wang \& Ke 2002). We measured metal assimilation efficiency from ingested food and influx from the dissolved phase, and quantified metal body burdens and MT concentrations in whelks that had differential MT concentrations. Whelks with different MT concentrations were obtained from metal-enriched and clean field-populations and by exposure to aqueous and dietary $\mathrm{Cd}$.

\section{MATERIALS AND METHODS}

Gastropods and exposure. The effects of MTs on metal accumulation were determined using the whelk Thais clavigera from field-populations with elevated MT concentrations and groups that were exposed to aqueous and dietary $\mathrm{Cd}$ to induce MT synthesis. Whelks Thais clavigera (shell length of 25 to $30 \mathrm{~mm}$ and tissue weight of $\sim 0.2 \mathrm{~g}$ ) were collected from 11 sites in the coastal waters of Hong Kong. The sites chosen (Fig. 1) represent a range of hydrographical and anthropogenic metal enrichment conditions (Blackmore 1998). Sites 1 (Tuen Mun), 2 (Tai O) and 3 (South Lantau) are heavily affected by the low salinity discharges of the Pearl River. Sites 8 (Cape d'Aguilar) and 9 (Clear Water Bay) are wave-exposed, receiving oceanic water from the South China Sea. The University of Science and Technology (UST, Site 10), located within Port Shelter, is more sheltered from the influence of the South China Sea than Sites 8 and 9 but is still far from major urban and industrial developments. The Victoria Harbor sites (Queen's Pier, 5, and Tsim Sha Tsui, 6), Aberdeen (Site 7) and Tsing Yi (Site 4) are at the historical center of the main urban and industrial development areas. Starfish Bay, Tolo Harbor (Site 11), is sheltered and is located on the edge of an area that was developed in the 1980s as industry translocated from the more central areas around Victoria Harbor.
Whelks, collected from piers and rocks, were placed in a clean polythene bag and transported to the laboratory where they were frozen at $-80^{\circ} \mathrm{C}$. The whelks were subsequently defrosted, but kept cold $\left(<4^{\circ} \mathrm{C}\right)$, and the leiblein gland dissected out. The leiblein gland was chosen for MT analysis (methods described below) since it is a sensitive and important gland in MT synthesis (Leung \& Furness 1999a). After the MT analysis, 2 populations (Starfish Bay and UST sites) were chosen on the basis of MT body concentrations (as indicated by leiblein gland MT concentration) and local abundance (i.e. ease of collection) for further bioaccumulation study. Starfish Bay whelks were chosen to represent a low MT concentration and UST whelks a high concentration.

In addition to the 2 field populations (Starfish Bay and UST) which were directly used for the bioaccumulation study, we also conducted laboratory $\mathrm{Cd}$ preexposure to examine the influences of MT induction on metal bioaccumulation. Thais clavigera collected from UST (Site 10) were used for the laboratory exposure experiments (Expt 1). They were exposed in groups to dissolved $\mathrm{Cd}$ at 50,100 or $400 \mu \mathrm{g} \mathrm{l}^{-1}$ for $14 \mathrm{~d}$. These concentrations, while environmentally unrealistic, were necessary in order to achieve higher Cd concentrations than the background tissue levels due to the low Cd uptake from the dissolved phase. The whelks were maintained in aerated seawater and kept at a constant temperature of $20^{\circ} \mathrm{C}$. Another 3 groups were fed (ad libitum) Cd-enriched mussel Perna viridis digestive gland, oyster Saccostrea cucullata digestive gland, or the barnacle Balanus amphitrite. The prey

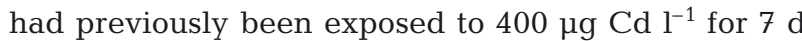
and then frozen at $-80^{\circ} \mathrm{C}$. The dissolved exposure and control (clean seawater collected from UST-nominal $\mathrm{Cd}$ concentration of $0.055 \mu \mathrm{g} \mathrm{l}^{-1}$ ) groups were fed (ad libitum) with the barnacle $B$. amphitrite. After $14 \mathrm{~d}$ exposure, a portion of whelks were frozen at $-80^{\circ} \mathrm{C}$ for MT determination (kidney, digestive gland, and leiblein gland) and whole body $\mathrm{Cd}$ concentration analysis. The remaining individuals from 3 groups, i.e. those exposed to dissolved $100 \mu \mathrm{g} \mathrm{Cd} \mathrm{l}^{-1}$, those fed Cdenriched oyster $S$. cucullata digestive glands, and the control, were subsequently used in metal accumulation experiments. $\mathrm{Cd}$ and $\mathrm{Zn}$ influx from the dissolved phase, and their assimilation efficiencies from ingested food source, were determined in each group, using methods described below.

A second dissolved $\mathrm{Cd}$ pre-exposure experiment was conducted with Thais clavigera collected from Starfish Bay in order to investigate its influence on $\mathrm{Hg}$ assimilation (Expt 2). Whelks were exposed to dissolved Cd at 5, 20 or $100 \mu \mathrm{g} \mathrm{l}^{-1}$ for $14 \mathrm{~d}$. A control group without a $\mathrm{Cd}$ spike was also included in the experiment. During the experimental period, whelks were 
kept as outlined above. Following exposure, Hg assimilation efficiency and kidney MTs concentrations were determined in each group, using methods described below.

Metal uptake from the dissolved phase. Eight Thais clavigera from each group were placed individually into $200 \mathrm{ml}$ of $0.22 \mu \mathrm{m}$ filtered seawater. The water was spiked with stable metals and radiotracers $\left({ }^{109} \mathrm{Cd}\right.$ and ${ }^{65} \mathrm{Zn}$ ) which were equilibrated overnight. A range of metal concentrations were used in the metal uptake experiments to allow calculation of the uptake rate constant. The levels were $0.5,2,8$ and $20 \mu \mathrm{g} \mathrm{l}^{-1}$ for $\mathrm{Cd}_{\text {, }}$ and 2, 8, 20 and $100 \mu \mathrm{g} \mathrm{l}^{-1}$ for $\mathrm{Zn}$. Radioisotope additions were $1.85 \mathrm{kBq} \mathrm{l}^{-1}$ for $\mathrm{Cd}$ and $3.7 \mathrm{kBq} \mathrm{l}^{-1}$ for $\mathrm{Zn}$. The radioactivity of the exposure medium was measured at the start and end of the experiment. Depletion of dissolved $\mathrm{Cd}$ and $\mathrm{Zn}$ was assumed to be negligible since radioactivity was similar. Care was taken to keep the whelks submerged. Following $24 \mathrm{~h}$ exposure, whelks were dissected and the soft tissues radioassayed. The relatively long exposure ( $24 \mathrm{~h}$ ) was necessary since previous experiments have shown that dissolved uptake in whelks was much slower as compared to bivalves (Leung \& Furness 1999a). The tissues were then dried at $80^{\circ} \mathrm{C}$ and dry weights determined. Uptake rate were calculated as the amount of metal accumulated by the soft tissues of whelks divided by the exposure duration and standardized to nanogram dry weight per $\mathrm{h}\left(\mathrm{ng} \mathrm{g}^{-1} \mathrm{~h}^{-1}\right)$.

Metal assimilation efficiency. The oyster Saccostrea cucullata was radiolabeled following $14 \mathrm{~d}$ of aqueous exposure to $37 \mathrm{kBq}$ of ${ }^{109} \mathrm{Cd}$ and $74 \mathrm{kBq}$ of ${ }^{65} \mathrm{Zn}$ (Expt 1), or $37 \mathrm{kBq}{ }^{203} \mathrm{Hg}$ (Expt 2), after which time the prey was considered uniformly labeled. Previous work has shown that uptake from a bivalve prey by a predatory gastropod varies little following prey labeling either by aqueous or food (algae) exposure (Wang \& Ke 2002). Oyster digestive glands were chosen as prey because the whelks fed readily on these when compared to other prey. Furthermore, oysters form a common component of the diet in the field (Blackmore 2000), where their digestive gland are selectively preyed upon. Digestive glands were dissected out of the radiolabeled oysters and placed individually in a tray of water. Whelks were then added individually and allowed to feed on the digestive glands for $1 \mathrm{~h}$, after which they were rinsed in seawater and radioassayed. Whelks were then tagged and 10 individuals were placed in 31 of seawater. Fecal pellets were collected and water was changed regularly (at least twice a day) to minimize desorption of radiotracers. Whelks were fed ad libitum on the barnacle Balanus amphtrite. Barnacles were chosen as food because of their small size (i.e. unconsumed tissue would not foul the water). The whelks were radioassayed at 3 to $12 \mathrm{~h}$ intervals over the $72 \mathrm{~h}$ depuration period. Assimilation efficiencies were determined as the percentage of initial radioactivity retained in Thais clavigera after $60 \mathrm{~h}$.

MT determination. MTs were determined using a modified (Leung \& Furness 1999a) silver saturation method (Scheuhammer \& Cherian 1986). Soft tissues from 15 individual whelks were removed and their wet weight determined. The leiblein gland, kidney and digestive gland/gonad complex were dissected out. These tissues were chosen because they are important and sensitive tissues in MT induction (Leung \& Furness 1999a). Care was taken to keep the samples at $4^{\circ} \mathrm{C}$ or below. The tissues were weighed and then homogenized in $4 \times$ vol. of cold $0.25 \mathrm{M}$ sucrose buffer. The homogenate was centrifuged at $4^{\circ} \mathrm{C}$ at $20000 \times g$ for $20 \mathrm{~min}$. The supernatant was separated from the pellet and frozen at $-80^{\circ} \mathrm{C}$ until MT determination. The supernatant $(0.3 \mathrm{ml})$ was later incubated with $1 \mathrm{ml}$ of $10 \mu \mathrm{g}{ }^{110 \mathrm{~m}} \mathrm{Ag} \mathrm{m} \mathrm{m}^{-1}$ (activity $0.18 \mathrm{kBq} \mathrm{ml}^{-1}$ ) in $0.5 \mathrm{M}$ glycine buffer at room temperature for $10 \mathrm{~min}$. This step saturated the MT binding sites with Ag. Excess Ag was removed with the addition of $0.1 \mathrm{ml}$ rabbit red blood cell haemolysate (Scheuhammer \& Cherian 1991), followed by heat treatment $\left(100^{\circ} \mathrm{C}\right.$ for $\left.5 \mathrm{~min}\right)$ and centrifugation $(5 \mathrm{~min}$ at $1200 \times g$ ). Heat treatment caused precipitation of Ag bound to hemoglobin and other proteins but not the MTs, which are heat-stable. The addition of haemolysate, heat treatment and centrifugation was repeated twice more. The amount of Ag present in the final supernatant is proportional to the MT concentration and was determined following radioassaying for ${ }^{110 \mathrm{~m}} \mathrm{Ag}$. MT concentrations were calculated as $3.54 \times$ the Ag concentrations when fully saturated (1 $\mu \mathrm{g} \mathrm{Ag} \mathrm{ml}^{-1}$ is bound to $3.54 \mu \mathrm{g} \mathrm{MT} \mathrm{ml} \mathrm{m}^{-1}$ ) (Scheuhammer \& Cherian 1986). All MT concentrations were expressed as $\mu \mathrm{g} \mathrm{g}^{-1}$ wet weight tissue units.

Analytical measurements. Radioactivity was measured using a Wallac gamma counter. Spillover of radioisotopes was corrected and all counts were related to standards for each isotope and corrected for radioactive decay. The gamma emissions of ${ }^{110 \mathrm{~m}} \mathrm{Ag}$ were determined at $658 \mathrm{keV},{ }^{109} \mathrm{Cd}$ at $88 \mathrm{keV},{ }^{203} \mathrm{Hg}$ at $279 \mathrm{keV}$, and ${ }^{65} \mathrm{Zn}$ at $1115 \mathrm{keV}$. Counting times in all samples were adjusted so that the propagated counting errors were typically $<5 \%$.

Whelks used to determine body metal concentrations were first depurated for $2 \mathrm{~d}$ in clean seawater and then frozen at $-80^{\circ} \mathrm{C}$. At a later date, 15 whelks from each group or site were dissected and the soft tissues dried at $80^{\circ} \mathrm{C}$ to constant weight and then digested at $100^{\circ} \mathrm{C}$ in concentrated nitric acid. Dilutions were analyzed for $\mathrm{Cd}, \mathrm{Cu}$ and $\mathrm{Zn}$ using Inductively Coupled Plasma Mass Spectrophotometry (ICP-MS). Throughout the analyses, random checks were made using aliquots of a certified reference material (Standard 


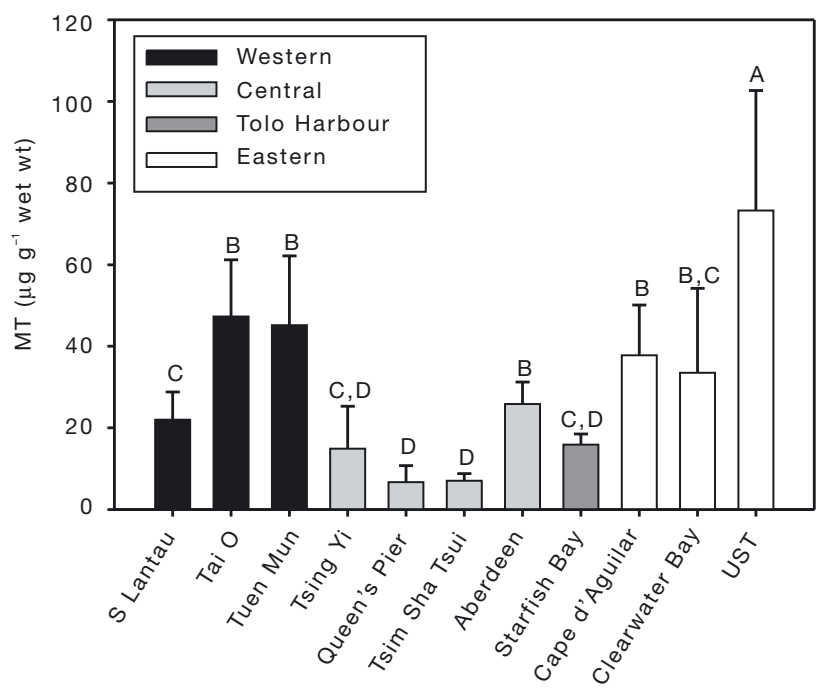

Fig. 2. Thais clavigera. Metallothionein (MT) concentrations in whelks collected from 11 sites in the coastal waters of Hong Kong. See Fig. 1 for sampling locations. Mean \pm SD $(n=15)$. Sites sharing the same letter do not differ significantly $(p>0.05)$

Reference Material 1566a Oyster tissue, National Institute of Standards and Technology, Gaitherburg, MD). Agreement was within $10 \%$. All metal concentrations were expressed as $\mu \mathrm{g} \mathrm{g}^{-1}$ dry weight.

Data were tested to confirm the assumptions of parametric tests and investigated using analysis of variance (ANOVA). Unplanned comparisons (post hoc tests) were carried out to establish the ranking with respect to MT concentrations by using multiple comparisons with Bonferroni's correction to determine significance using SAS 6.12.

\section{RESULTS AND DISCUSSION}

\section{Relationships between MT and metal concentrations}

The MT concentrations in the leiblein gland of Thais clavigera collected from around the coastal waters of Hong Kong are shown in Fig. 2. There was significant $(p<0.01)$ inter-site variability in the leiblein gland MT levels. Leiblein gland MT concentrations were highest in those individuals collected from UST and $>10 \times$ lower in those collected from Queen's Pier, Victoria Harbour. The high MT concentration measured from UST was not accompanied with the relatively low dissolved Cd concentration at this site $(0.5 \mathrm{nM})$, implying that other environmental conditions may be responsible for the MT induction (Leung et al. 2000). The MT levels measured in the present study are comparable to those measured in a temperate species of neogastro- pod, i.e. Nucella lapillus (Leung et al. 2000). Such levels were, however, much lower than those reported from cephalopod digestive glands (Bustamante et al. 2002), but similar to those found in Littorina littorea (Leung \& Furness 1999b) and much higher than those found in mussels and clams (G.B. \& W.X.W. unpubl. data). Fig. 3 shows the relationship between the MT concentrations and the $\mathrm{Cd}, \mathrm{Cu}$ and $\mathrm{Zn}$ body burdens in T. clavigera. There was a significant relationship ( $\mathrm{p}=$ 0.006) between Cd body concentrations and MTs but there was no such relationship for $\mathrm{Cu}(\mathrm{p}=0.225)$ and $\mathrm{Zn}(\mathrm{p}=0.657)$.

The quantified Cd concentration in the whelks in the control treatments (without Cd exposure) was $12.5 \pm$ $1.6 \mu \mathrm{g} \mathrm{g}^{-1}$ dry weight. Following exposure to dissolved $\mathrm{Cd}$, the $\mathrm{Cd}$ tissue burden increased to $22.6 \pm 1.5 \mathrm{\mu g} \mathrm{g}^{-1}$, $41.3 \pm 1.4 \mu \mathrm{g} \mathrm{g}^{-1}, 130 \pm 15.6 \mu \mathrm{g} \mathrm{g}^{-1}$, in the $\mathrm{Cd}^{2} 0 \mu \mathrm{g} \mathrm{l}^{-1}$, $100 \mu \mathrm{g} \mathrm{l}^{-1}$, and $400 \mu \mathrm{g} \mathrm{l^{-1 }}$ treatment respectively.

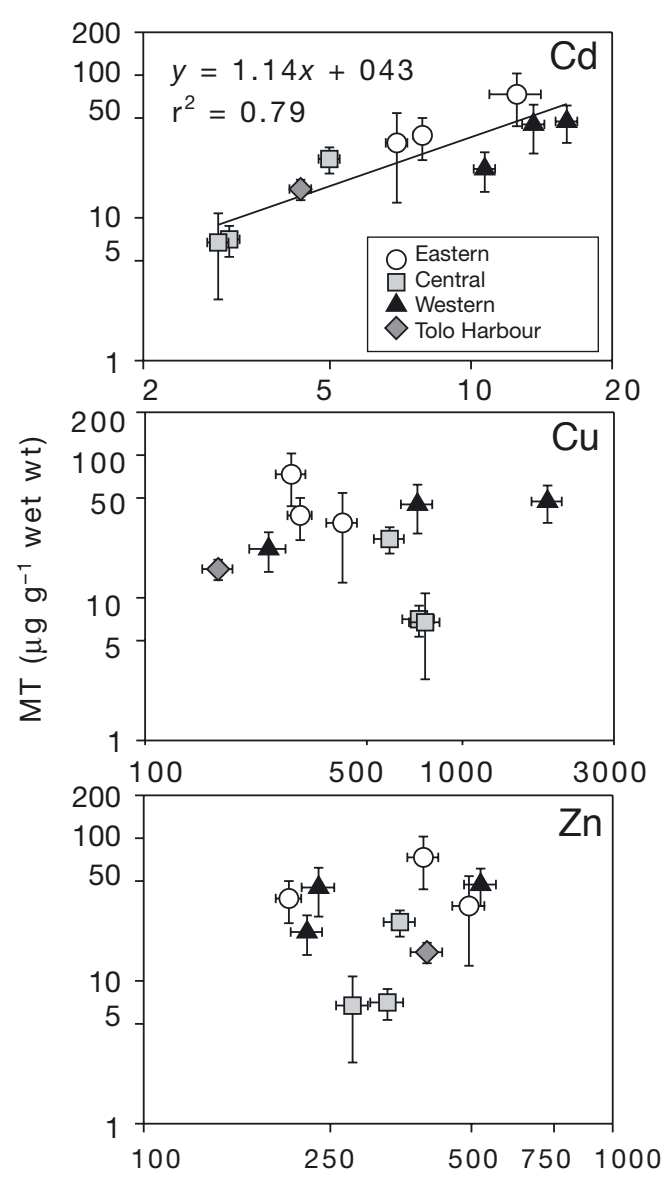

Metal concentration ( $\mu \mathrm{g} \mathrm{g}^{-1}$, dry wt)

Fig. 3. Thais clavigera. Relationship between metallothionein (MT) concentrations and $\mathrm{Cd}, \mathrm{Cu}$ and $\mathrm{Zn}$ body concentrations in whelks collected from 11 sites in the coastal waters of Hong Kong. Mean $\pm \mathrm{SD}(\mathrm{n}=15)$ 

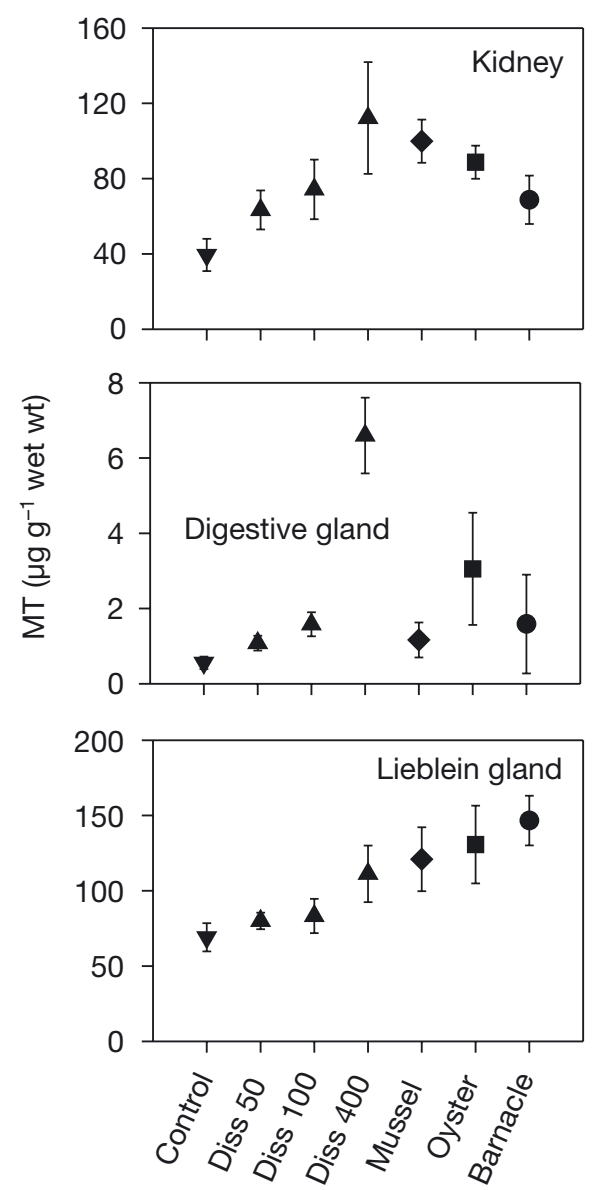

Fig. 4. Thais clavigera. Metallothionein (MT) concentrations in different tissues of the whelks following pre-exposure to different dissolved $\mathrm{Cd}$ concentrations and dietary $\mathrm{Cd}$ from different preys. Diss 50: dissolved Cd concentration of $50 \mu \mathrm{g}$ $\mathrm{l}^{-1}$; Diss 100: dissolved Cd concentration of $100 \mathrm{\mu g} \mathrm{l}^{-1}$; Diss 400: dissolved Cd concentration of $400 \mu \mathrm{g} \mathrm{l}^{-1}$. Mean $\pm \mathrm{SD}$ $(\mathrm{n}=15)$

Increases in Cd tissue burden following dietary exposure to different prey appeared to be relatively smaller compared to the aqueous $\mathrm{Cd}$ exposure. The $\mathrm{Cd}$ tissue burden was $19.3 \pm 1.6 \mu \mathrm{g} \mathrm{g}^{-1}, 15.6 \pm 3.5 \mu \mathrm{g} \mathrm{g}^{-1}, 18.6 \pm$ $1.7 \mathrm{\mu g} \mathrm{g}^{-1}$, following feeding on barnacles, oyster digestive glands, and mussel digestive glands respectively. The MT concentrations in the kidney, leiblein gland and digestive gland of Thais clavigera (collected from UST) following $14 \mathrm{~d}$ of exposure to aqueous $\mathrm{Cd}$ or Cd-enriched food are shown in Fig. 4. In agreement with Fig. 2, the control MT concentrations in the leiblein gland were similar to those of the fieldcollected T. clavigera from UST. This suggests that a $14 \mathrm{~d}$ experimental exposure period had very little effect on MT concentrations and presumably MT synthesis in the control treatment. Following exposure to dissolved $\mathrm{Cd}$ and $\mathrm{Cd}$-enriched food, MT concen- trations increased 1.6 to $2.8 \times$ in the kidney, 1.9 to $11.9 \times$ in the digestive gland and 1.2 to $2.1 \times$ in the leiblein gland when compared to the control. MT concentrations were similar in the leiblein gland and kidney (63.4 to $120 \mathrm{\mu g} \mathrm{g}^{-1}$ wet weight) and were much higher $(>30 \times)$ when compared to the digestive gland (1.08 to $6.60 \mathrm{\mu g} \mathrm{g}^{-1}$ wet weight). This result agrees with previous work on marine snails, which shows that the MT concentration in the kidney is much greater than in the digestive gland (Leung \& Furness 1999a). Furthermore, MT concentrations in the leiblein gland, which is restricted to neogastropods, have been shown to be high and increase dramatically following exposure to Cd (Leung \& Furness 1999a). This tissue is therefore considered an important and sensitive tissue for MT induction (Leung \& Furness 1999a).
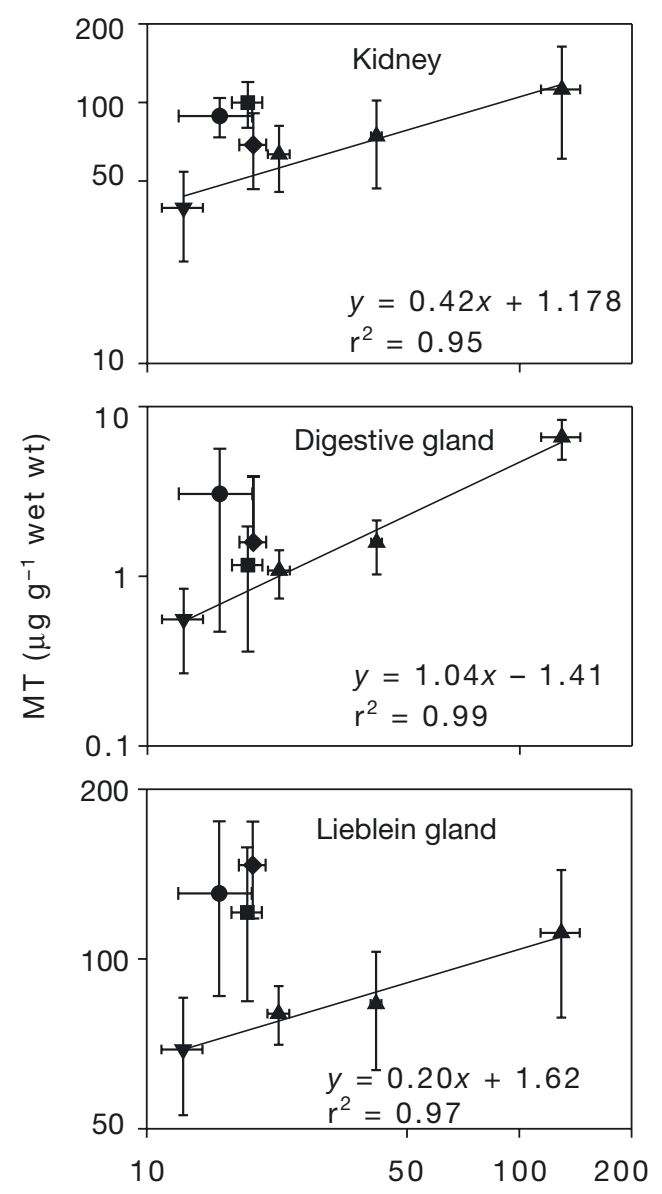

Body Cd concentration ( $\mu \mathrm{g} \mathrm{g}^{-1}$, dry wt)

Fig. 5. Thais clavigera. Relationship between metallothionein (MT) concentrations and Cd body concentrations in whelks. Linear regression was performed for dissolved groups only. ( $\mathbf{\Delta}$ ) dissolved exposure; ( $\mathbf{\nabla})$ control; $(\boldsymbol{\bullet})$ fed on Cd-enriched oyster digestive gland; $(\bullet)$ fed on Cd-enriched barnacle; $(\bullet)$ fed on Cd-enriched mussel digestive gland. Mean \pm SD $(\mathrm{n}=15)$ 
In contrast to the results for dissolved Cd exposure, there was no clear pattern of MT concentrations following feeding upon Cd-enriched food (Fig. 4). For example, whelks that had been fed Cd-enriched Perna viridis digestive glands had the highest concentrations of MTs in the kidney but the lowest concentrations in the digestive gland, when compared to whelks fed on the other 2 food types. Those individuals that had been fed Cd-enriched Balanus amphitrite had the highest levels of MT in the leiblein gland but the lowest levels in the kidney. MT concentrations were $\sim 40$ to $90 \times$ lower in the digestive glands, when compared to the other 2 tissues. However, in contrast to the dissolved exposure individuals, MT levels were 1.2 to $2.1 \times$ higher in the leiblein gland when compared to the kidney. In general, MT concentrations following feeding upon Cdenriched prey were comparable to those of the dissolved exposure in both the kidney (64.5 to $112 \mu \mathrm{g}$ $\mathrm{g}^{-1}$ wet weight) and the digestive gland (1.08 to $6.60 \mu \mathrm{g} \mathrm{g}^{-1}$ wet weight), whereas MT concentrations were $1.5 \times$ greater in the leiblein gland after dietary exposure, presumably due to the important role this tissue plays in digestion.

There was a significant relationship between the MT concentration in all 3 tissues and the $\mathrm{Cd}$ body concentration following dissolved Cd exposure (Fig. 5). These results agree with our field-collected Thais clavigera, i.e. MT concentrations increase with $\mathrm{Cd}$ exposure, which is also reflected in accumulated body burdens. Similarly, George \& Olsson (1994) concluded that MT concentrations are generally correlated with metal concentrations. In contrast, there was no clear pattern between $\mathrm{Cd}$ body concentration resulting from dietary exposure and MT concentration in any tissue (Fig. 5). MT concentrations for a given body $\mathrm{Cd}$ concentration were much higher following food exposure compared to the same body concentration derived from dissolved exposure (Fig. 5). Wang \& Ke (2002) reported that for 2 predatory gastropods Nassarius teretiusculus and Babylonia formasae habei, intake of $\mathrm{Cd}$ and $\mathrm{Zn}$ is dominated by the dietary sources. Blackmore (2000) and Blackmore \& Morton (2002) suggest that diet may be the most important source of both $\mathrm{Cu}$ and $\mathrm{Zn}$ to $T$. clavigera. This may help explain why there was no correlation between $\mathrm{MT}$ concentration and $\mathrm{Cu}$ and $\mathrm{Zn}$ body concentrations in the field-collected whelks (Fig. 2), since there was no clear relationship between dietary exposure and MT levels. T. clavigera can have significantly different body $\mathrm{Cu}$ and $\mathrm{Zn}$ concentrations depending on the resident prey community (Blackmore 2000). The presence or absence of strong net metal accumulators such as oysters and barnacles is particularly important (Blackmore 2000, Blackmore \&
Morton 2002). Thus T. clavigera $\mathrm{Cu}$ and $\mathrm{Zn}$ body concentrations often do not agree with the established contamination gradients (Rainbow \& Blackmore 2001).

There was however a significant relationship between field MT levels and Cd body burdens. In Hong Kong, there was very little interspecific body Cd concentration variation in the potential prey items of Thais clavigera (Blackmore 1999), and body concentrations generally match dissolved metal bioavailabilities. Thus, body concentrations in the predator correspond well to dissolved bioavailabilities, even though diet is the major source of Cd (Bryan et al. 1983). Previous validation of MT as suitable biomarkers of metal contamination has focused on the dissolved exposure. The significance of dietary source for metal bioaccumulation has recently been recognized (Wang \& Fisher 1999, Blackmore 2000, Wang 2002). This study further suggests that the route of metal uptake affects resultant MT concentrations. Clearly, this has important implications for the use of MT as a biomarker of metal pollution especially where the dietary source predominates.

\section{Metal-dissolved uptake at different MT concentrations}

The influx of $\mathrm{Cd}$ and $\mathrm{Zn}$ into whelks with differential MT concentrations is shown in Fig. 6. Cd influx in Thais clavigera (3.07 to $5.33 \mathrm{ng} \mathrm{g}^{-1} \mathrm{~h}^{-1}$ ) was $\sim 5 \times$ lower when compared to mussels Perna viridis, Mytilus edulis, M. trossulus and M. galloprovincialis (14.1 to $19.2 \mathrm{ng} \mathrm{g}^{-1} \mathrm{~h}^{-1}$ ) at a dissolved Cd concentration of $2 \mu \mathrm{g}$ $\mathrm{l}^{-1}$ (Blackmore \& Wang 2003a). Similarly, Zn influx was $\sim 4 \times$ lower in whelks (14.1 to $20.4 \mathrm{ng} \mathrm{g}^{-1} \mathrm{~h}^{-1}$ ) when compared to mussels ( 37.1 to $50.5 \mathrm{ng} \mathrm{g}^{-1} \mathrm{~h}^{-1}$ ) at a dissolved concentration of $8 \mu \mathrm{g} \mathrm{l}^{-1}$. The relationships between metal influx and ambient $\mathrm{Cd}$ and $\mathrm{Zn}$ concentrations are shown in Table 1. For all treatments and both metals there was a significant $(p<0.01) \log -\log$ linear relationship between influx and dissolved concentration. The coefficients of this relationship were close to 1, indicating that uptake proceeded by absorption/ facilitated transport and conformed to Freundlich isotherms. These results agree with similar literature for bivalve mussels (Wang \& Fisher 1999).

Dissolved uptake rate by Thais clavigera varied little ( $p>0.05$ ) among laboratory treatments and between field populations. MT thus had no clear or consistent effect on the dissolved uptake of $\mathrm{Cd}$ or $\mathrm{Zn}$. This result is again in agreement with works on bivalves (Blackmore \& Wang 2002, 2003a). For example, dissolved uptake rate among mussel species (Perna viridis, Mytilus spp.) and among collection locations (England, China and 


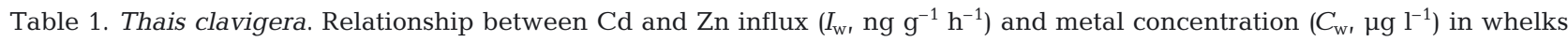
with differential MT concentrations. $\log I_{\mathrm{w}}=a+b \log C_{\mathrm{w}}$. Data are mean $\pm \mathrm{SD}$

\begin{tabular}{|c|c|c|c|c|c|c|}
\hline \multirow{2}{*}{ Treatment } & \multicolumn{3}{|c|}{$\longrightarrow \mathrm{Cd} \longrightarrow$} & \multicolumn{3}{|c|}{$\longrightarrow$ Zn } \\
\hline & a & $b$ & $r^{2}$ & a & $b$ & $\mathrm{r}^{2}$ \\
\hline \multicolumn{7}{|l|}{ Field population } \\
\hline UST (high MT) & $0.18 \pm 0.036$ & $1.02 \pm 0.047$ & 0.94 & $0.47 \pm 0.059$ & $1.02 \pm 0.046$ & 0.94 \\
\hline SFB (low MT) & $0.11 \pm 0.041$ & $1.06 \pm 0.053$ & 0.93 & $0.44 \pm 0.059$ & $1.02 \pm 0.046$ & 0.93 \\
\hline Post hoc & & $\mathrm{p}>0.05$ & & & $\mathrm{p}>0.05$ & \\
\hline \multicolumn{7}{|l|}{ Lab Cd pre-exposure } \\
\hline Control & $0.33 \pm 0.038$ & $0.98 \pm 0.049$ & 0.94 & $0.61 \pm 0.049$ & $0.98 \pm 0.038$ & 0.96 \\
\hline Dissolved Cd (100 $\left.\mu \mathrm{g} \mathrm{l}^{-1}\right)$ & $0.33 \pm 0.041$ & $1.01 \pm 0.062$ & 0.97 & $0.53 \pm 0.075$ & $1.01 \pm 0.067$ & 0.98 \\
\hline Cd-enriched diet & $0.31 \pm 0.030$ & $1.01 \pm 0.040$ & 0.93 & $0.66 \pm 0.042$ & $0.93 \pm 0.033$ & 0.93 \\
\hline Post hoc & & $\mathrm{p}>0.05$ & & & $\mathrm{p}>0.05$ & \\
\hline
\end{tabular}

USA) were largely similar despite differing soft tissue concentrations (Blackmore \& Wang 2003a). Furthermore, Blackmore \& Wang (2002) reported that $\mathrm{Cd}$ and Zn influx were similar in the green mussel $P$. viridis with elevated body $\mathrm{Cd}$ and MTLP concentrations and following $\mathrm{Cd}$ pre-exposure. Pre-exposure to $\mathrm{Zn}$, however, resulted in a decrease in Cd and Zn influx but there was no increase in MTLP levels. Boisson et al. (1998) found that following chronic exposure to Ag in a contaminated estuary, the clam Macoma balthica accumulated Ag at a significantly lower rate than conspecifics collected from a clean estuary, but MT levels were not quantified in their study. In contrast to Cd exposure, Ag (Boisson et al. 1998, Shi et al. 2003) and Zn (Blackmore \& Wang 2002) have been shown to trigger reductions in dissolved uptake in bivalves but do not have a clear concomitant effect on MT levels.

\section{Metal assimilation at different MT concentrations}

Depuration of $\mathrm{Cd}, \mathrm{Hg}$, and $\mathrm{Zn}$ in whelks is shown in Fig. 7. Metals were rapidly egested initially, after which much less was lost from the whelks. A higher fraction of $\mathrm{Zn}$ was egested as compared to $\mathrm{Cd}$ and $\mathrm{Hg}$. These depuration patterns agree with data from other marine invertebrates (Chong \& Wang 2000, Rainbow \& Wang 2001). Assimilation efficiencies (AEs) were calculated as the amounts of radioactivity left in the organism at $60 \mathrm{~h}$ divided by the amount ingested, measured following the pulse radioactive feeding (Table 2). In contrast to the dissolved exposure, AEs were affected by differential MT concentrations. The assimilation of $\mathrm{Cd}$ and $\mathrm{Zn}$ by Thais clavigera was not signifi- cantly different (ANOVA: $\mathrm{p}=0.27$ for $\mathrm{Cd}$ and $\mathrm{p}=0.38$ for $\mathrm{Zn}$ ) in whelks collected from Starfish Bay and UST, although Cd AEs were higher in the population (UST) with the greater MT body concentration. Cd AE was 12 to $14 \%$ greater (ANOVA: $\mathrm{p}<0.01$ ) in those individuals that had elevated MT body concentrations following exposure to aqueous and dietary $\mathrm{Cd}$ when compared to the controls. Hg assimilation was significantly higher (14 to $28 \%, \mathrm{p}<0.01$ ) following dissolved Cd exposure and concomitant increases in MTs (Table 2) in a separate $\mathrm{Cd}$ pre-exposure experiment. In this experiment, the MT concentration in the kidney was $12.7 \pm 3.7 \mu \mathrm{g}$ $\mathrm{g}^{-1}$ in the control treatment, and this concentration increased to $15.1 \pm 2.6,31.4 \pm 7.0$, and $48.1 \pm 20.0 \mu \mathrm{g} \mathrm{g}^{-1}$ in

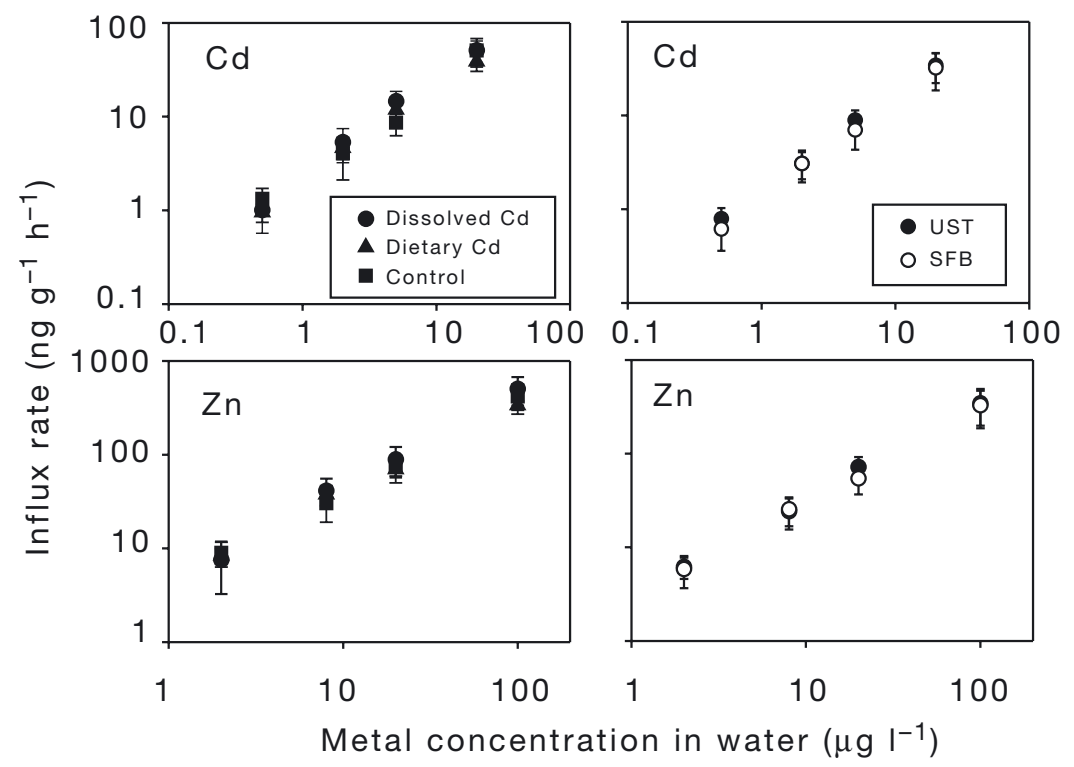

Fig. 6. Thais clavigera. Cd and Zn uptake rates in whelks with differential concentrations of metallothioneins following exposure to aqueous or dietary Cd (left panels) or originating from more or less impacted field populations (right panels). SFB: Starfish Bay, Site 11; UST: University of Science and Technology, Site 10. Mean \pm SD $(n=8)$ 
the 5, 20, and $100 \mu \mathrm{g} \mathrm{l} \mathrm{l}^{-1} \mathrm{Cd}$ exposure treatments respectively. In contrast, the Zn AE showed the opposite pattern, i.e. assimilation in the groups with higher MT was significantly lower (ANOVA: $\mathrm{p}<0.01$ : 79 to $88 \%$ ) compared to the controls. Previous studies have indicated that there was considerable variation between AEs obtained within each experiment (Wang 2002). Such variation in AEs may be explained by subtle differences in feeding rates, digestive physiology and condition of the prey.

The assimilation of both $\mathrm{Cd}$ and $\mathrm{Hg}$ in whelks was generally higher in individuals with a higher MT concentration. The induction of MTs may have provided more binding sites available for $\mathrm{Cd}$ and $\mathrm{Hg}$ sequestration. However, the overall induction capacity of MT, which may be metal-specific, remains unknown. The results for $\mathrm{Zn}$ were more complicated. Following laboratory exposure, there was a negative relationship between Zn AE and MT, but this pattern was reversed in the field populations. Following laboratory Cd exposure it is likely that any synthesized MTs become saturated by $\mathrm{Cd}$ binding compared to $\mathrm{MT}$ in control groups. Zn has a lower binding affinity for MT com-
Table 2. Thais clavigera. Cd, $\mathrm{Hg}$ and $\mathrm{Zn}$ assimilation efficiencies (AEs, \%) in whelks with differential MT concentrations. Data are mean $\pm \operatorname{SD}(n=5)$. nm: not measured

\begin{tabular}{|c|c|c|c|}
\hline Treatment & $\mathrm{Cd}$ & $\mathrm{Hg}$ & $\mathrm{Zn}$ \\
\hline \multicolumn{4}{|l|}{ Field population } \\
\hline UST (high MT) & $90.9 \pm 9.2$ & $\mathrm{~nm}$ & $68.2 \pm 8.6$ \\
\hline SFB (low MT) & $85.5 \pm 4.4$ & $\mathrm{~nm}$ & $62.7 \pm 9.8$ \\
\hline Post hoc & $\mathrm{p}=0.27$ & & $\mathrm{p}=0.375$ \\
\hline \multicolumn{4}{|l|}{ Lab Cd pre-exposure } \\
\hline \multicolumn{4}{|l|}{ Expt 1} \\
\hline Control (C) & $74.0 \pm 4.6$ & $\mathrm{~nm}$ & $66.3 \pm 5.0$ \\
\hline $\begin{array}{l}\text { Dissolved Cd } \\
\left(100 \mu \mathrm{g} \mathrm{l}^{-1}\right)(\mathrm{D})\end{array}$ & $84.0 \pm 4.2$ & $\mathrm{~nm}$ & $58.4 \pm 5.0$ \\
\hline Cd-enriched diet $(\mathrm{F})$ & $82.7 \pm 3.7$ & $\mathrm{~nm}$ & $52.4 \pm 5.8$ \\
\hline Post hoc & $\begin{array}{l}\mathrm{p}<0.01: \\
\mathrm{D}=\mathrm{F}>\mathrm{C}\end{array}$ & & $\begin{array}{c}\mathrm{p}<0.01 \\
\mathrm{C}>\mathrm{D}=\mathrm{F}\end{array}$ \\
\hline \multicolumn{4}{|l|}{ Expt 2} \\
\hline Control (C) & $\mathrm{nm}$ & $72.0 \pm 5.4$ & $\mathrm{~nm}$ \\
\hline $\begin{array}{l}\text { Dissolved Cd } \\
\left(5 \mu^{-1}\right)(\mathrm{D} 5)\end{array}$ & $\mathrm{nm}$ & $79.8 \pm 6.0$ & $\mathrm{~nm}$ \\
\hline $\begin{array}{l}\text { Dissolved Cd } \\
\left(20 \mu \mathrm{g} \mathrm{l}^{-1}\right)(\mathrm{D} 20)\end{array}$ & $\mathrm{nm}$ & $81.2 \pm 4.8$ & $\mathrm{~nm}$ \\
\hline $\begin{array}{l}\text { Dissolved Cd } \\
\left(100 \mathrm{gg}^{-1}\right)(\mathrm{D} 100)\end{array}$ & $\mathrm{nm}$ & $92.3 \pm 6.0$ & $\mathrm{~nm}$ \\
\hline Post hoc & \multicolumn{3}{|c|}{$\begin{array}{c}\mathrm{p}<0.01: \\
\mathrm{D} 100>\mathrm{D} 20=\mathrm{D} 5=\mathrm{C}\end{array}$} \\
\hline
\end{tabular}
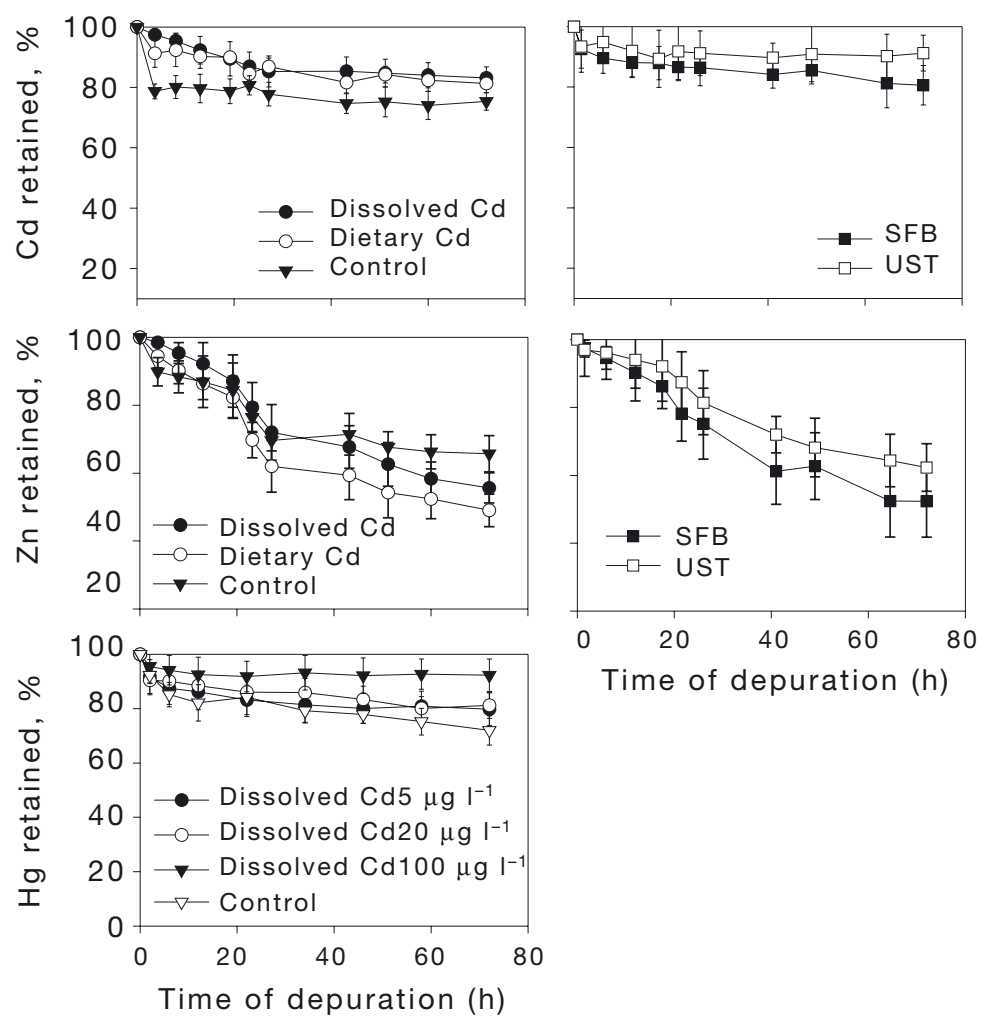

Fig. 7. Thais clavigera. Retention of $\mathrm{Cd}_{1} \mathrm{Hg}$, and $\mathrm{Zn}$ in whelks with differential concentrations of metallothioneins following exposure to aqueous or dietary Cd (left panels) or originating from more or less impacted field populations (right panels) following a pulse ingestion of radiolabeled oyster Saccostrea cucullata digestive glands. SFB: Starfish Bay, Site 11; UST: University of Science and Technology, Site 10. Mean \pm SD $(n=5)$ pared to Cd (Roesijadi 1996) and would thus be unable to displace $\mathrm{Cd}$. Consequently, the reduction in intracellular Zn binding resulted in a lower assimilation by the whelks. In the field populations MTs may have been induced by a variety of factors and it is unlikely that MTs were saturated by a particular metal, thus $\mathrm{Zn}$ AE increased with increasing MT concentration.

Our results for metal AE were in contrast to dissolved metal influx, where no effect was noted in individuals with differential metal MT levels. Other studies have found that dissolved uptake is typically less sensitive to intracellular physiological changes (e.g. synthesis of MTs) (Blackmore \& Wang 2002) and differential body metal burdens (Shi et al. 2003, Blackmore \& Wang 2003a). Dissolved uptake is a passive process and is controlled largely by physico-chemical factors, e.g. changes in the free ion concentration. Physiology may, however, affect dissolved metal uptake particularly where membrane permeability has been changed (Rainbow 1995, Rainbow \& Black 2002, Blackmore \& Wang 2003b).

Our study suggests a link between MT levels and increased assimilation of metals by whelks from dietary sources, in particular for $\mathrm{Cd}$ and $\mathrm{Hg}$. This is true for field populations 
with differential MT levels and for whelks in which MTs were induced following laboratory exposure to $\mathrm{Cd}$. It is interesting to note that there was a clear relationship between MT concentration and dissolved $\mathrm{Cd}$ exposure and $\mathrm{Cd}$ field body burdens. The importance of metal accumulation from dietary pathways in marine animals is becoming increasingly clear. There was, however, no apparent relationship between MT concentrations and body $\mathrm{Cd}$ concentrations following dietary exposure to $\mathrm{Cd}$. Given the dominance of dietary metal uptake, the use of MTs as biomarkers of metal contamination should be treated with caution. Furthermore, relationships between dietary metal accumulation and biomarker expression remain to be further investigated.

Acknowledgements. We thank 4 anonymous reviewers for their useful comments on this work. This study was supported by a Competitive Earmarked Research Grant from the Hong Kong Research Grants Council (HKUST6097/02M) to W.X.W. G.B. was also supported by a postdoctoral fund from the Hong Kong University of Science and Technology.

\section{LITERATURE CITED}

Bebianno MJ, Langston WJ (1993) Turnover rate of metallothionein and cadmium in Mytilus edulis. BioMetals 6 $239-244$

Blackmore G (1998) An overview of trace metal pollution in the coastal waters of Hong Kong. Sci Total Environ 214:21-48

Blackmore G (1999) Temporal and spatial biomonitoring of heavy metals in Hong Kong coastal waters using Tetraclita squamosa. Environ Pollut 106:273-283

Blackmore G (2000) Field evidence of metal transfer from invertebrate prey to an intertidal predator, Thais clavigera (Gastropoda: Muricidae). Estuar Coast Shelf Sci 51: 127-139

Blackmore G, Morton B (2002) The influence of diet on comparative trace metal cadmium, copper and zinc accumulation in Thais clavigera (Gastropoda: Muricidae) preying on intertidal barnacles or mussels. Mar Pollut Bull 44: 870-876

Blackmore G, Wang WX (2002) Uptake and efflux of Cd and Zn by the green mussel Perna viridis after metal preexposure. Environ Sci Technol 36:989-995

Blackmore G, Wang WX (2003a) Comparison of metal accumulation in mussels at different local and global scales. Environ Toxicol Chem 22:288-395

Blackmore G, Wang WX (2003b) Inter-population differences in $\mathrm{Cd}, \mathrm{Cr}$, Se and $\mathrm{Zn}$ accumulation by the green mussel Perna viridis acclimated at different salinities. Aquat Toxicol 62:205-218

Boisson F, Hartl MGJ, Fowler SW, Amiard-Triquet C (1998) Influence of chronic exposure to silver and mercury in the field on the bioaccumulation potential of the bivalve Macoma balthica. Mar Environ Res 45:325-340

Bryan GW, Langston WJ, Hummerstone LG, Burt GR, Ho YB (1983) An assessment of the gastropod, Littorina littorea, as an indicator of heavy metal contamination in United Kingdom estuaries. J Mar Biol Ass UK 63:327-345

Bustamante P, Cosson RP, Gallien I, Caurant F, Miramand P (2002) Cadmium detoxification processes in the digestive gland of cephalopods in relation to accumulated concentrations. Mar Environ Res 53:227-241

Chong K, Wang WX (2000) Assimilation of cadmium, chromium and zinc by the Green Mussel Perna viridis and the clam Ruditapes philippinarum. Environ Toxicol Chem 19:1600-1667

George SG, Olsson PE (1994) Metallothioneins as indicators of trace metal pollution. In: Krammer KJM (ed) Biomonitoring of coastal waters and estuaries. CRC Press, Boca Raton, FL, p 151-178

Gully JR, Mason AZ (1993) Cytosolic redistribution enhanced accumulation of $\mathrm{Cu}$ in gill tissue of Littorina littorea as a result of Cd exposure. Mar Environ Res 35:53-57

Hamer DH (1986) Metallothionein. Ann Rev Biochem 55: 913-951

Langston WJ, Bebianno MJ, Burt GR (1998) Metal handling strategies in molluscs. In: Langston WJ, Bebianno MJ (eds) Metal metbolism in aquatic environments, Chapman \& Hall, London, p 219-283

Langston WJ, Chesman BS, Burt GR, Pope ND, McEvoy J (2002) Metallothionein in liver of eels Anguilla anguilla from the Thames estuary: an indicator of environmental quality? Mar Environ Res 53:263-293

Legras S, Mouneyrac C, Amiard JC, Amiard-Triquet C, Rainbow PS (2000) Changes in metallothionein concentrations in response to variation in natural factors (salinity, sex, weight) and metal contamination in crabs from a metal rich estuary. J Exp Mar Biol Ecol 246:259-279

Leung KMY, Furness RW (1999a) Induction of metallothionein in dogwhelk Nucella lapillus during and after exposure to cadmium. Ecotoxicol Environ Saf 43:156-164

Leung KMY, Furness RW (1999b) Effects of animal size on concentrations of metallothionein and metals in periwinkles Litttorina littorea collected from the Firth of Clyde, Scotland. Mar Pollut Bull 39:126-136

Leung KMY, Taylor AC, Furness RW (2000) Temperaturedependent physiological responses of the whelk Nucella lapillus to cadmium exposure. J Mar Biol Ass UK 80:1-14

Mouneyrac C, Amiard JC, Amiard-Triquet C (1998) Effects of natural factors (salinity and body weight) on cadmium, copper, zinc and metallothionein-like protein levels in resident populations of oysters Crassostrea gigas from a polluted estuary. Mar Ecol Prog Ser 162:125-135

Mouneyrac C, Geffard A, Amiard JC, Amiard-Triquet C (2000) Metallothionein-like proteins in Macoma balthica: effects of metal exposure and natural factors. Can J Fish Aquat Sci 57:34-42

Olsson PE, Haux C, Förlin L (1987) Variations in hepatic metallothionein, zinc and copper levels during an annual reproductive cycle in rainbow trout Salmo gairdneri. Fish Physiol Biochem 3:39-47

Overnell J, McIntosh R, Fletcher TC (1988) Factors affecting metallothionein levels in marine flatfish. Mar Environ Res 24:155-158

Palmiter RD (1994) Regulation of metallothionein genes by heavy metals appear to be mediated by a zinc sensitive inhibitor that interacts with a constitutively active transcription factor MTF-1. Proc Nat Acad Sci USA 91: 1219-1223

Phillips DJH, Rainbow PS (1993) Biomonitoring of aquatic trace contaminants. Chapman \& Hall, London

Rainbow PS (1995) Biomonitoring of heavy metal availability in the marine environment. Mar Pollut Bull 31: 55-59

Rainbow PS, Black WH (2002) Effects of changes in salinity and osmolality on the rate of uptake of zinc by three crabs of different ecologies. Mar Ecol Prog Ser 244:205-217

Rainbow PS, Blackmore G (2001) Barnacles as biomonitors 
of trace metal availabilities in Hong Kong coastal waters: changes in space and time. Mar Environ Res 51: 441-463

Rainbow PS, Wang WX (2001) Comparative assimilation of $\mathrm{Cd}, \mathrm{Cr}$, Se and $\mathrm{Zn}$ by the barnacle Eliminus modestus from phytoplankton and zooplankton diets. Mar Ecol Prog Ser 218: $239-248$

Roesijadi G (1992) Metallothioneins in metal regulation and toxicity in aquatic animals. Aquat Toxicol 22:81-114

Roesijadi G (1994) Metallothionein induction as a measure of response to metal exposure in aquatic animals. Environ Health Perspect 102:91-95

Roesijadi G (1996) Metallothionein and its role in toxic metal regulation. Comp Biochem Physiol 113C: 117-123

Scheuhammer AM, Cherian MG (1986) Quantification of metallothioneins by a silver saturation method. Toxicol Appl

Editorial responsibility: Otto Kinne (Editor),

Oldendorf/Luhe, Germany
Pharmacol 82: 417-425

Scheuhammer AM, Cherian MG (1991) Quantification of metallothionein by silver saturation. Methods Enzymol 205: 78-82

Shi DL, Blackmore G, Wang WX (2003) Effects of aqueous and dietary preexposure and resulting body burden on silver biokinetics in the green mussel Perna viridis. Environ Sci Technol 37:936-943

Wang WX (2002) Interactions of trace metals and different marine food chains. Mar Ecol Prog Ser 243:295-309

Wang WX, Fisher NS (1999) Delineating metal accumulation pathways for marine invertebrates. Sci Total Environ 237/238:459-472

Wang WX, Ke C (2002) Dominance of dietary intake of cadmium and zinc by two marine predatory gastropods. Aquat Toxicol 56:153-165

Submitted: October 20, 2003; Accepted: April 8, 2004

Proofs received from author(s): August 3, 2004 